\title{
To the Readers and Authors of Skin Pharmacology and A pplied Skin Physiology
}

\section{Dear Colleagues,}

As the editorship has changed hands, in my new function as Editor-in-Chief I would like to thank you for your interest and contributions to our journal.

Also, I would like to take this opportunity to thank Hans Merk, who has, as Editor, successfully developed the journal in the past years. The last year, when we shared the editorship, was very stimulating for me. I'm sure that the fruitful co-operation with Hans Merk as an Honorary Editor wil be continued in the future. I will do my best to further develop the journal.

In addition, I would like to thank all the Associate Editors, Board Members and Reviewers of Skin Pharmacology and Applied Skin Physiology, the excellent work of whom is pivotal for the quality of our journal. The number of manuscripts that we receive every month is continuously increasing. The selection of a strictly limited number of good papers for publishing in our journal was not an easy task.

Last but not least, I would like to thank the readers of Skin Pharmacology and Applied Skin Physiology for their continued interest in our journal and for their helpful hints and proposals.

Please note that the Guidelines for Authors have been amended. The contributors are kindly asked to submit an electronic version (on disk or by e-mail) with the manuscript to the Editorial Office of Skin Pharmacology and Applied Skin Physiology in Basel.

I wish you a happy, successful and peaceful New Year.

With best personal regards,

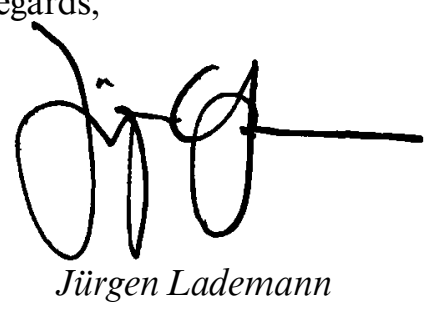

\begin{tabular}{ll}
\hline KARGER & @ 2003 S. Karger AG, Basel \\
1422-2868/03/0161-0003\$19.50/0 \\
$\begin{array}{l}\text { Fax +4161306 12 34 } \\
\begin{array}{l}\text { E-Mail karger@karger.ch } \\
\text { www.karger.com }\end{array}\end{array}$ & $\begin{array}{l}\text { Accessible online at: } \\
\text { www.karger.com/sph }\end{array}$
\end{tabular}

